\title{
TREVISAN, Dalton. Rita Ritinha Ritona. Rio de Janeiro: Record, 2005.
}

Sérgio Alves Peixoto

Universidade Federal de Minas Gerais

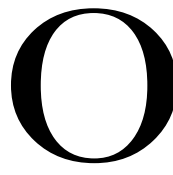

mais recente livro de contos de Dalton Trevisan não nega a verve do autor curitibano. Seus textos continuam sendo trabalhados com um misto de ironia e amargura. Ao todo, 17. Curitiba, a mesma: sempre povoada por seres mesquinhos e, nem por isso, menos dignos de pena. Sexo e mais sexo: até à pornografia. "O amor, essa coisa, sabe como é", dizem os personagens de "Almoço em família" e "O estripador", dois contos do livro. Não sabemos, não; estamos à procura dele como o Vampiro de Curitiba, à cata de si mesmo.

Dos dezessete contos, alguns se destacam.

Primeiro, e não necessariamente nessa ordem, "O gringo", por não falar explicitamente da Curitiba comumente retratada. A narrativa se passa numa ilha. Os personagens são pescadores e antigos imigrantes. Rudolph e Greta, os principais. Ele, como um bom anti-herói de Dalton, é "viciado em bebida, charuto e mulher gorda. Qualquer mulher". Ela, a mesma Maria dos contos primeiros, em eterna disputa com seu João, a quem continua ligada pelo sofrimento e pelo medo de se ver sozinha na velhice. A mesma relação sado-masoquista de quase sempre.

A "Balada das mocinhas da rua do Passeio" e "Amintas 749", também se destacam pelo formato. São escritos em, diríamos, versos não rimados.

$\mathrm{Na}$ "Balada", alguma coisa da famosa "Balada do mangue", de Vinícius de Morais. Principalmente, as metáforas espantosamente criativas relacionadas às "mulheres de vida fácil": "centopéias do horror", "galinhas de duas cabeças", "treponemas pálidos", "íbis sagradas de carapinha negra", "aracnídeas hotentotes", "gárgulas banguelas gargalhantes", "doces ninfetas 
putativas do Passeio". A última metáfora poderia estar entre as de Vinícius; as outras são monstruosas demais para o poetinha.

No outro, "Amintas 749", fala-se de um endereço famoso de Curitiba, onde uma sauna gay se apresenta mais medonha que o Inferno de Dante. Nela, "a bacanal começa quando você chega" e "todas as perversões bizarrias taras/todas são aceitas nenhuma restrição/desconto de $15 \%$ ao maníaco sexual/velhinho pedófilo uranista/sádico masoquista coprófilo/pai de família enrustido ou não". É nessa sauna que blasfêmia! - diria ironicamente um personagem de Dalton, se venera a "imagem luminosa giratória/de Nosso Jesusinho do Falo Erecto". O ambiente é digno dos mais deprimentes do escritor. Um Dalton em tom maior.

Diferente, também, quis ser "O mestre e a aluna", no qual "O Grande Inquisidor das monografias" transa com a orientanda até o paroxismo. Mas é um conto menor. A famigerada intertextualidade o estraga. Nele, uma aluna leva, ao orientador, sua monografia sobre Dom Casmurro, para avaliação e, é claro, acaba fundindo-se à Capitu traidora do romance de Machado. Sabe-se que Dalton é do grupo que defende a traição da mulher de Bentinho (se isso é perda de tempo, são outros quinhentos). Tematizar isso num conto é, porém, torná-lo ingênuo demais, sem nenhuma criatividade, na verdade. Como é ingênuo ficar-se, como boa parte da crítica universitária hoje em dia, perdendo tempo, deslumbrada ante tais e tais intertextualidades, seja onde for. Se tudo hoje é intertextualidade, ela acaba não sendo nada. Vejamos como a Capitu devassa de Dalton nos fala sobre o assédio do professor:

$\mathrm{O}$ mestre me introduz no escritório. Instala-se atrás da grande escrivaninha, inchada de papéis e livros. Indica uma cadeira à sua frente. Folheia $\mathrm{o}$ trabalho. Duas ou três perguntas. Apruma-se na poltrona e me concede um sorriso.

- Agora podemos conversar.

Estende o bracinho curto.

- Aqui mais perto.

Ai de mim, bem o que eu temia. O que, na minha vez, faria Capitu? Não se sacrificou ao marido e senhor para sua ascensão social? Deve o mesmo a esse asno pomposo e pançudo? Se não vou, já sei: nota insufi-ciente, reprovação, a carreira truncada.

Enquanto que, em Dom Casmurro, o tom é sério, no conto de Dalton a "pobrezinha" vai se transformar na devassa nada espantada com o que terá de fazer, mas com o prazer que está sentindo: 
Ele se recosta na cadeira. Me deixa de pé entre seus joelhos. - Tire a blusinha.

Começo a desabotoar numa confusão de dedos. Presa ao grito dos seus olhos. Espantada. Mais de mim que dele. Euzinha, quem diria.

Entre todos os contos do livro, dois são excepcionais. Destacam-se pela concisão e pela beleza melancólica da narrativa. São eles "Adeus, vampiro" e "A ponte".

No primeiro, Nelsinho, herói preferido de Dalton, acorda transformado "numa espécie encantada de vampiro". A transformação, não é, porém, kafkiana. E a intertextualidade, aqui, é quase fruto do acaso. O vampiro se humaniza, fica romanticamente lírico, "tem coração de pintassilgo". Continua a perseguir o prazer, sim, mas não amedronta; é predador e vítima, como nos diz o narrador:

Esse vampiro, quem diria, tem coração de pintassilgo. Ou corruíra, se assim prefere. Já não crava os caninos e as garras - mais chegado a sábios toques e blandícias erógenas. Para merecer o beijo puro na catedral do amor é capaz de voar, sim, voar nas asas brancas da luxúria. E, a fim de alcançar um gozo proibido, com todo o vampirismo desce da nobreza e, de joelhos e mãozinha posta, faz o que o seu benzinho quer.(...)

O meu vampiro é um doce traficante de ilusões. Inofensivo? Nem tanto. Esconde o humor atrás do óculo azul e as trancinhas rastafári. Um vampiro tímido, já pensou? (...)

O meu vampiro não é viageiro das sombras. Um mutante que ama, sim, o ar livre: capa preta (o forro vermelho de seda) ao vento, pedala fagueiro pelas ciclovias.

No segundo, "A ponte", nem sombra de erotismo. Algo como a tristeza de "Uma vela para Dario", conto antigo, de um de seus primeiros e mais belos livros, Cemitério de elefantes, quando ainda não se encontrava obcecado com sexo. A mãe perde a filha e pensa em se suicidar, atirando-se da ponte do título. Ironicamente, antes do último ato, escorrega, cai e morre. Crianças atiram-lhe pedras ao corpo meio afundado, por não saberem o que é. Uma sombra de sorriso triste tolda-lhe o rosto, já no caixão. E o narrador nos diz, finalizando a narrativa: "Mas tão triste, que antes não sorrisse”. Aí está um dos melhores livros da recente safra de Dalton. Pico certeiro na veia do leitor. 